\title{
The Attitude of the Local Population Towards Vietnamese Boat People in Hong Kong
}

\author{
by Lawrence Lam
}

\section{The context}

In the past ten years, Hong Kong has responded to the Vietnamese Boat People in three distinctive ways, ranging from initially a positive humanitarian response in 1975 to a developing negative reaction since 1982 , culminating in the endorsement of the forced repatriation of 51 Boat People from a detention centre who, on December 11, 1989, at 3:00 am, were literally "taken from their beds, bundled into caged trucks," driven to the airport under tight security (200 heavily armed riot police) and cover of darkness, and placed on a specially chartered flight to Hanoi. This approach has gained overwhelming support from the Hong Kong people who believed that they have done as much as possible to house the Boat People.

While this approach has drawn criticism from other countries, it was justified on two grounds: a) the Boat People being repatriated are not genuine refugees but illegal immigrants seeking better economic opportunities; and b) to send a clear signal back to the would-be Vietnamese Boat People in Vietnam to deter them from arriving in Hong Kong when the monsoon season ends in March. In addition, as the attitude of Hong Kong people has become increasingly hostile towards the Vietnamese Boat People, this approach is probably a deliberate attempt by the British government to show them that the "mother country is doing something for the colony" and to satisfy the demand made by China that every Vietnamese must be out by 1997 when China takes over Hong Kong.
With over 50,000 Vietnamese Boat People in Hong Kong (as of August, 1989), and regardless of cries of protest (hunger strikes, demonstrations) in refugee camps and expressions of profound regret by countries such as Canada's, this forced repatriation is likely to continue as the solution to the Vietnamese Boat People crisis in Hong Kong unless a concerted effort is taken by the international community to effectively stop the continuing influx of Boat People into Hong Kong and/or launching launching a program to accept an increasing number of them for resettlement.

\section{The attitude towards Vietnamese Boat People}

Analyzing the Hong Kong people's attitude towards these refugees is a complicated task, because its root cause is not immediately apparent. It involves an acute sense of "helplessness" among Hong Kong people, particularly as a response to the June 1989 crisis in China. There is also a sense of "betrayal" and "abandonment" experienced by them in relation to the "right of abode" issue with the UK government. As well, a sense of being "victimized" resulting from the "power struggle" between the UNHCR and the UK is widely felt by the Hong Kong people. Hence, they do not want to be "burdened and troubled" by these "uninvited and unwelcome invaders." To understand this composite picture, it is necessary to take note of several factors:

1) As 1997 approaches (by a negotiated treaty between the UK and China, with minimal participation of the Hong Kong government and people), Hong Kong will revert back to China. This by itself has created what is commonly known as "1997 jitters" resulting in thousands upon thousands of Hong Kong people applying for immigration to Canada, Australia, the USA and other places. However, many of the Hong Kong people, responding to the 10 years of "open door" policy instituted by the Beijing regime, are somewhat "hopeful" or, at least carried a certain level of "guarded optimism" that "business will be as usual" and their "life" will not be greatly or unduly "disrupted and dislocated." However, the June 1989 crisis in China provided a rude awakening. For many of them, there is no "escape route" from the impending "upheaval;" the sense of helplessness is acutely felt. While they make attempts to alleviate this sense of helplessness by capturing every opportunity to apply for visas to immigrate (for example, when Singapore announced in early August 1989 that criteria for accepting immigrants from Hong Kong would be greatly relaxed, literally thousands of people lined up at the Singapore High Commission overnight to get an application form, and, when completed, paid a sum of HK $\$ 1,200$ for processing), international communities such as the USA, the UK, Canada, Australia, and others do not take any interest in "listening" to their impending plight, and least of all, "offering" them an "escape route." On the other hand, meetings were held to discuss the Vietnamese Boat People. Implicitly or explicitly, Hong Kong was "criticized" for its treatment towards the refugees and was 
"threatened" (US Senator Solaz's visit to Hong Hong in August 1989) that it would bear the consequence of being rejected by other countries when they themselves would be in a similar situation as a result of the 1997 takeover of Hong Kong by the Chinese government. This indeed has intensified their sense of helplessness and uncertainty in the near future.

2) The sense of "betrayal" and "abandonment" is directly related to the British government in its negotiation with the Chinese regime in Beijing. By and large, the "wheeling and dealing" was conducted, in the minds of Hong Kong people, without their "input" and without their "interest" being considered. They believed that the British government failed to negotiate a treaty with the Chinese regime that would guarantee their "security and stable future" in Hong Kong; and to provide them with an "escape route" in terms of granting them the right of abode in the UK had the situations after 1997 demanded. As over 3 million of the 6 million Hong Kong people were born there, as British subjects holding British passports, they believe that they have the inalienable right of abode in the UK However, not only has the British government denied them this right, but in spite of increasing opposition towards the Vietnamese Boat People, it has insisted on maintaining Hong Kong as the first port of asylum - that is, imposing upon its colony the requirement that it continue the "open door policy" for incoming Vietnamese Boat People while it has neither increased its involvement in resettling these Boat People, nor sought to secure a viable solution with the international communities to the Boat People crisis in Hong Kong, nor made substantial contributions either in financial terms or in kind to the running and maintaining of refugee camps. For example, in view of recent disturbances in different refugee camps, it was suggested that

instead of over-stretching the limited resources of the Police force in Hong Kong, the British army stationed there and supported by the Hong Kong taxpayers should be drafted to keep order. However, this suggestion was turned down with the explanation that this British army was not "trained" for civilian and/or police duties. The rejection was interpreted by the Hong Kong people as another indication of the British government's policy of "betrayal and abandonment." Worse, some Hong Kong people have interpreted this rejection, in conjunction with other issues mentioned, (e.g., maintaining Hong Kong as the first port of asylum), as a hidden agenda by the British government to bleed Hong Kong to death before the 1997 turn over.

3) As Hong Kong continues, reluctantly, to be the first port of asylum for the continuing influx of Vietnamese Boat People, it is not directly involved in the decisionmaking process. Any decision made is seen as a "power struggle" between the two major players in the game - the UNHCR and the UK with the USA calling the tune behind the scenes, while Hong Kong is either totally ignored or, at most, allowed to assume the role of "spectator." Its citizens feel "victimized" as "pawns" in the game. For example, with repatriation as the "game" played between the major players, the UNHCR, with the support of the USA, insists that this has to be done completely voluntarily on the part of the Vietnamese Boat People. The British government has yet to clearly spell out its position. The Hong Kong government, in spite of overwhelming support of the Hong Kong people for "repatriating" those Vietnamese Boat People who are "screened out" as non-refugees back to Vietnam, has been asked to approve additional funding to construct new refugee camps to reduce the overcrowded conditions in some existing camps (temporary holding centres) as well as to improve the living conditions for the Vietnamese Boat People in the existing camps. While the major players continue to seek a solution to settle the score and the Hong Kong people continue to pay the UN's share of running the camps (the UN has yet to reimburse HK $\$ 5$ million for the fiscal year of 1989 , to the Hong Kong government), repatriation is seen as a "farce." First, the number of Vietnamese Boat People voluntarily repatriated is small in comparison with arrivals. For example, on August 18, 1989, as the third group of some 121 Vietnamese Boat People leaving for Vietnam on board a jet, some 548 Boat People arrived in Hong Kong by sea. Second, since each repatriate was given a certain sum of money (US $\$ 50$ ) by the UNHCR prior to departure and often times, they used this sum of money to buy "luxurious items" in Hong Kong to bring back "home," the repatriation is seen as an "invitation" to other Vietnamese in Vietnam to come to Hong Kong. Indeed, there were reported cases that among the "newly arrived" Vietnamese Boat People, some were "ex-repatriates." (The UNHCR in Hong Kong initially denied this and later admitted that there might be a few cases.) Nevertheless, the sense of being "victimized" as a result of not being able to be "master of one's own home" is deeply and widely felt by the Hong Kong people.

In addition to the abovementioned factors underscoring the largely negative attitude towards the Vietnamese Boat People in Hong Kong, a fuller comprehension of Hong Kong people's reaction to the Vietnamese Boat People requires a close examination on the following factors:

1) Jealousy: With the impending "take over" of Hong Kong by the Chinese regime, many Hong Kong people are trying to find an "escape route" by emigrating to other countries. In contrast to the Vietnamese Boat People, it appears that the chance for the latter to leave is much better than that of the Hong Kong people since the Vietnamese Boat People are still the subject of discussion in the international community. However, while the Hong Kong people are "crying out" for attention to their impending plight 
and "making attempts" to alleviate this increasingly "heightened level of anxiety," they are at the same time forced to support others by letting them have the very chance which they have come to believe as the "solution" to their "problems." Hence, in spite of the appalling living conditions in camps, they are at least a step ahead of the Hong Kong people in terms of leaving for other secure places before the inevitable establishment of a larger refugee camp in Hong Kong, this time for the Hong Kong people.

(2) Sense of injustice: As a substantial portion of the Hong Kong people left China for Hong Kong in 1949 when the People's Republic of China was established, some still have relatives or even family members in China. The Hong Kong immigration regulations have made "family reunion" a difficult and long-drawn process. In addition, in an attempt to stem the flow of "illegal immigrants" from China entering Hong Kong, a policy of "immediate repatriation" was instituted between Hong Kong and China. In other words, if a person from China who is not a legal resident of Hong Kong is caught by the Hong Kong police in their routine checks of identity papers (every Hong Kong resident by law has to carry his/her identity card for inspection when asked to produce it by the police) he or she will be immediately sent back to China. There are cases of relatives and/or family members of Hong Kong residents, who bypassed the "normal process" of obtaining immigrant visas, being sent back to China. For example, in August 1989 a legal resident of Hong Kong went on a hunger strike to protest the government's decision not to allow his son to stay with him in Hong Kong. This case, once vividly reported in the media, has intensified the feeling of injustice which was aptly reflected and captured by the following statement: "We spend millions of dollars for the Vietnamese Boat People, why can't we afford to accept this little boy?!"

3) Location of camps: In an effort to alleviate the overcrowded conditions in the refugee camps, particularly in the temporary holding centres, new camps are to be constructed. However, the decision of where the camp should be constructed is, by and large, made by the government without any consultation with the local people. Recently the government decided to build a new refugee camp within the vicinity of a reservoir in an outlying district. This choice drew criticism and protest from the Hong Kong people. Their reaction to this was undoubtedly related to what the media reported - instances of Vietnamese Boat People polluting the waters in and around their refugee camps. Therefore, the Hong Kong people do not believe, in spite of numerous assurances from the government, that security measures and other amenities built in the new camp would make it virtually impossible for the Vietnamese Boat People to do anything that would pollute the drinking water of the Hong Kong people. Nor do they believe that the government is taking their legitimate concerns seriously. Instead, the government is taking orders directly from the UK to improve the living conditions for the Vietnamese Boat People so as to appease the UNHCR and the international community to distract from the criticism of the inhumane treatment of the refugees.

The Hong Kong people not only had feelings, they acted. Their concerted efforts included a sit-in, demonstrations, camping on the proposed refugee camp site for nine days (they were ultimately removed by the police). Their suggestion of an alternate site failed to convince the government to change the decision. As such, they felt that not only was their legitimate concern totally ignored, but, more importantly, the "interest and welfare" of the Vietnamese Boat People was unreasonably given priority.

Combined with these various factors, media reports depicting criminal activities of Vietnamese Boat People, and saying that the latter were given priority in medical treatment (reluctantly admitted by one clinic close to a refugee camp when they stated that they treated the Boat People brought in by authorities first because they did not want too many of them roaming around there while waiting for treatment) have effectively "hardened" the negative attitude of the Hong Kong people, who already lived in limited limited and congested living space, towards the Vietnamese Boat People as "unwanted and unwelcome people." The Vietnamese Boat People, the Hong Kong residents argued, usurped the already limited social and medical services, while the Hong Kong residents' "uncertainty" about their own future heightened daily.

\section{Concluding remarks}

The analysis of Hong Kong people's attitude towards the Vietnamese Boat People underscores the fact that any solution to the "Boat People crisis" has to address the concerns deeply felt by the Hong Kong Kong people. As an August 1989 survey indicated, about two thirds of the Hong Kong people urged the Hong Kong government not to approve additional funding for building new refugee camps and that an even greater portion of them would like the Hong Kong government to "press" the British government to end the policy of making Hong Kong the first port of asylum, even though they realized that their "opinion and effort" would be a futile exercise. However, without addressing their concerns directly, efforts and measures taken to ease the plight of the Vietnamese Boat People in Hong Kong, particularly those currently in "closed centres," would merely fall on "deaf ears." The reason is that administrators and workers running these camps are themselves Hong Kong people who share and identify with the concerns of the rest of Hong Kong. Ultimately, it is conceivable that the Vietnamese Boat People (especially the women and children) may become the scapegoats and victims.

Lawrence Lam teaches sociology at York University. 